\title{
WOMEN IN REPRODUCTIVE SCIENCE Reproduction down under
}

\author{
Marilyn B Renfree \\ School of BioSciences, The University of Melbourne, Melbourne, Victoria, Australia \\ Correspondence should be addressed to M B Renfree; Email: m.renfree@unimelb.edu.au
}

This paper forms part of a focus section on Women in Reproductive Science. The guest editor for this section was Professor Marilyn Renfree, Ian Potter Chair of Zoology, School of BioSciences, The University of Melbourne, Victoria, Australia. Professor Renfree was not involved in the review or editorial process for this paper, on which she is listed as an author.

\begin{abstract}
Australia is home to a unique assembly of mammals - the marsupials and monotremes. Despite this uniqueness, they have been largely ignored by the biomedical scientific community, and yet study of marsupials has contributed to modern research on reproduction, development, evolution, conservation, molecular and comparative genomics. My lifetime passion for these longneglected Australian fauna has led to unexpected discoveries and insights that challenged assumptions and opened up new areas of international research. I used a range of disciplinary expertise to pursue the study of these unique mammals. My main experimental species has been the tammar wallaby that I have used as a model species to investigate and understand not only biomedical problems but also to provide knowledge that is critical for the continued conservation and management of Australia's dwindling native mammals. This model provided more than a few surprises for me and my wonderful team of students, post-docs and collaborators about how hormones, genes and signalling molecules control reproductive biology and development in a wider context as well as how the interactions of the environment with mother and conceptus, with mother and fetus and mother and young ultimately control most aspects of successful reproduction in mammals.

Reproduction (2019) 158 F127-F137
\end{abstract}

\section{Introduction: marsupial models}

Marsupials are best known for their cute young in pouches (Fig. 1), but not all marsupials have a pouch and of course no male marsupial has a pouch. The way in which marsupials differ most from their eutherian mammal counterparts is in their mode of reproduction (Tyndale-Biscoe \& Renfree 1987). They have a lengthy post-natal development during which the highly altricial young completes its development like an exteriorised fetus, dependent on their amazing milk that changes dynamically throughout the whole of lactation. It is these characteristics that have made them so attractive as experimental models for answering questions of the control and evolution of mammalian reproduction and development, although research granting bodies did not always see that research on Australia's interesting and exceptional mammals is worth funding!

Tackling these problems has necessitated field studies and collection largely from remote locations on South Australia's Kangaroo Island together with the establishment and maintenance of the largest marsupial breeding colony in the world in Melbourne, very much a hands-on activity, annually replenishing it with animals caught in the wild (at night) with my team of students, research fellows and colleagues from all over the world. This has required the development of knowledge about their handling and husbandry, and support (and extensive grant writing) to ensure the colony's long-term viability.

\section{Overturning entrenched ideas: the marsupial placenta and conceptus}

The term 'placental mammal' has been the bugbear of my career, because it gave people the impression that marsupials were aplacental mammals. Even textbooks to this day reiterate this erroneous conclusion. The placenta in most marsupials is an epitheliochorial placenta (like that of the pig), not an invasive chorio-allantoic (haemochorial) placenta (like that of mouse and man), but some, especially bandicoots, do have an allantoic placenta, and it is highly invasive, albeit for a very short time. During my PhD I was able to demonstrate that the relationship between the marsupial embryo and its mother is based on a fully functional placenta and that there is maternal recognition of pregnancy in which the embryo stimulates the endometrium to increase in size and to remain in a highly secretory condition, suggesting that the fetal effect may be either an endocrine factor or 


\section{My life with marsupials and other mammalian friends}

\section{Early days}

I was born in Brisbane after the war, and enjoyed climbing up jacaranda trees, eating pawpaw (papaya in the US) and being taken to the beach with my mum and dad and older siblings, Beverley and Neil. I think I must have been imprinted with marsupials from an early age. One of my earliest memories was visiting Lone Pine Sanctuary in Brisbane at around the age of 2, with my parents and being given a koala to cuddle. I'm sure this experience imprinted marsupials upon my subconscious! Not long after that, we moved to Canberra, the Australian capital (known still as the 'Bush Capital'). Canberra was tiny in those days but was a wonderful place to grow up - wonderful bush and animals, only $2 \mathrm{~h}$ from some of the best beaches in Australia, surfing and scuba diving, and two hours to the snow for skiing (both cross country and down-hill), and three-four hours from Sydney (for partying!).

\section{Mentors}

I have been so lucky with my mentors. First, Hugh Tyndale-Biscoe, a scientist of considerable

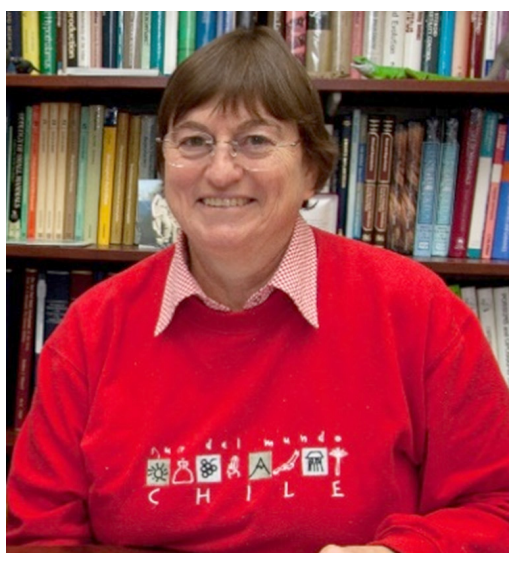
intellect, who constantly challenged me and who taught me to think outside the box was my honours and then PhD Supervisor. He was then (and still is now) demanding of high standards, and taught me a never ending curiosity about these Australian mammals. One of the most enjoyable phases of my association with Hugh was co-authoring our book, Reproductive Physiology of Marsupials (written, incidentally between daughter number 1 and daughter number 2). This book is known as 'The Bible' amongst my students, and despite its 1987 publishing date is still consulted on a frequent basis. Hugh taught me all things reproduction, sophisticated surgery and field work. He also taught me the value of clear writing and presentation. I met my other three amazing mentors Emmanuel Ciprian Amoroso, ('Amo' as he was universally known), Anne McLaren and Roger Short at an international conference in Canberra while I was a PhD student. Amo was the father of comparative placentation - a Trinidadian by origin based in London and Cambridge and a Fellow of the Royal Society - what an inspiration! I co-authored his very last review paper when I was on sabbatical in Babraham in Cambridge with Brian Heap. Little did I know then that of the other two, also Fellows of the Royal Society, one (Anne) would become a lifelong friend and surrogate grandmother to my children, and that the other (Roger) would become my husband and father of our two wonderful daughters, Dr Tamsin Short (clinical psychologist, especially forensic psychology) and Dr Kirsty Short (virologist, especially influenza).

I am a keen advocate for women in science, having received my fair share of discrimination when I was a younger researcher in my early academic positions. I have mentored (and kept in touch with) a large and enthusiastic cadre of former students and postdoctoral fellows who all occupy important positions in academic, research and pharmaceutical organizations throughout Australia and internationally. My closest colleague, Professor Geoff Shaw was my fourth PhD student, over 40 years ago, and we are still collaborating!

The one big advantage of working on unconventional animals is that you have to learn everything about these wild animals, from the anatomy, physiology, ecology, behaviour, molecular biology, genetics and genomics because there has been so much less information available than on common laboratory species like mice or domestic species like pigs and cows. It also meant that we had to work closely as a team, for it is very difficult to catch a wallaby by yourself!

\section{Career}

I have worked at six Universities in Australia, USA and UK: the Australian National University in Canberra, the University of Tennessee, the University of Edinburgh, Murdoch University in Perth, Monash University and Melbourne University both in Melbourne. Each endowed me with great experiences. After completion of my PhD at ANU supervised by Hugh Tyndale-Biscoe, I was awarded a Fulbright Fellowship to work with Joe Daniel at the University of Tennessee in Knoxville (where I became was known as the 'possum lady from Australia, learnt how to write a research grant and revised some of Carl Hartman's conclusions on opossum reproduction). I then was lucky enough to work on a Ford Foundation fellowship with Anne McLaren in Edinburgh (on mice!) at the ARC Institute of Animal Genetics where the famous Waddington was head of the Institute. In 1974, from Edinburgh, I was appointed as a foundation member of staff at the then brandnew University on Perth, Western Australia, Murdoch University, where I was a foundation Lecturer in Vertebrate Biology (only the third junior, non-Professorial member of staff) and where I established a 12 hectare (30 acres) Native Fauna Research Unit with tammars, agile wallabies and quokkas. Murdoch was truly a baptism by fire. We had no buildings, no campus, no laboratories, only temporary facilities in the Noalimba Migrant Centre in the suburb of Bullcreek, just down the road from the 600 acres of the Applecross Pine plantation that was to become Murdoch University. After almost ten years at Murdoch in early 1981, I became engaged to Roger Short, put my lab on hold in Murdoch and moved to Edinburgh once again, on a Royal Society Fellowship where I worked in the MRC Reproductive Biology Unit (led by Roger). We were married in Canberra in January 1982 and returned to Edinburgh. We were fortunate and forever grateful to both be recruited to Australia in May 1982 by Professors David de Kretser and Geoff Thorburn to the Department of Anatomy (Marilyn) and Physiology (Roger) at Monash University where I became an NHMRC Research Fellow. I held that fellowship until I moved to the University of Melbourne as Head of the Department of Zoology (now School of BioSciences) in 1991, where I remain to date.

\section{Concluding remarks}

I have, in the words of the Australian author Albert Lacey had 'A Fortunate Life'. I was lucky to have a supportive extended family, husband and children and supportive mentors. I was lucky that I could study and research my passion for Australian animals, and lucky that some discoveries have been translated into clinical medicine while others have been important for conservation. I've been lucky to be able to grab opportunities when they arose (together with the hard work that always accompanied these). Most of all I've been lucky in the fantastic cohort of national and international colleagues, students and Research Fellows who all have made this journey immensely exciting and rewarding with discoveries, mateship and adventure in some remote locations in Australia and internationally. They have all become part of my extended family.

My lifelong philosophy is summed up by my motto, a quotation from Johann Wolfgang von Goethe 'Whatever you can do or dream you can, begin it; Boldness has genius, power, and magic in it.' 


\section{Some important articles}

Cha J, Sun X, Bartos A, Fenelon J, Lefèvre P, Daikoku T, Shaw G, Maxson R, Murphy BD, Renfree MB et al. 2013 A new role for muscle segment homeobox genes in mammalian embryonic diapause. Open Biology 3 130035. (https://doi.org/10.1098/rsob.130035)

Chen Y, Yu H, Pask AJ, Fujiyama A, Suzuki Y, Sugano S, Shaw G \& Renfree MB 2018 Hormone-responsive genes in the SHH and WNT/ $\beta$-catenin signaling pathways influence urethral closure and phallus growth. Biology of Reproduction 99 806-816. (https://doi.org/10.1093/biolre/ioy117)

Chew KY, Shaw G, Yu H, Pask AJ \& Renfree MB 2014 Heterochrony in the regulation of the developing marsupial limb. Developmental Dynamics 243 324-338. (https://doi.org/10.1002/dvdy.24062)

Drews B, Roellig K, Menzies BR, Shaw G, Buentjen I, Herbert CA, Hildebrandt TB \& Renfree MB 2013 Ultrasonography of wallaby prenatal development shows that the climb to the pouch begins in utero. Scientific Reports 3 1458. (https://doi.org/10.1038/srep01458)

Foster JW, Brennan FE, Hampikian GK, Goodfellow PN, Sinclair AH, Lovell-Badge R, Selwood L, Renfree MB, Cooper DW \& Marshall Graves JA 1992 Evolution of sex determination and the $Y$ chromosome: SRY-related sequences in marsupials. Nature 359 531-533. (https://doi. org/10.1038/359531a0)

Frankenberg SR, Shaw G, Freyer C, Pask AJ \& Renfree MB 2013 Early cell lineage specification in a marsupial: a case for diverse mechanisms among mammals. Development 140 965-975. (https://doi.org/10.1242/dev.091629)

Frankenberg SR, de Barros FRO, Rossant J \& Renfree MB 2016 The mammalian blastocyst. Wiley Interdisciplinary Reviews: Developmental Biology 5 210-232. (https://doi.org/10.1002/wdev.220)

Gaeth AP, Short RV \& Renfree MB 1999 The developing renal, reproductive and respiratory systems of the African elephant suggest an aquatic ancestry. PNAS 96 5555-5558. (https://doi.org/10.1073/pnas.96.10.5555)

Graves JAM \& Renfree MB 2013 Marsupials in the age of genomics. Annual Review of Genomics and Human Genetics 14 393-420. (https://doi. org/10.1146/annurev-genom-091212-153452)

Harry JL, Koopman P, Brennan FE, Marshall Graves JA \& Renfree MB 1995 Widespread expression of the testis-determining gene, SRY, in a marsupial. Nature Genetics 11 347-349. (https://doi.org/10.1038/ng1195-347)

Hetz JA, Menzies BR, Shaw G, Rao A, Clarke IJ \& Renfree MB 2015 Growth axis maturation is linked to nutrition, growth and developmental rate. Molecular and Cellular Endocrinology 411 38-48. (https://doi.org/10.1016/j.mce.2015.04.009)

Johnson RN, O'Meally D, Chen Z, Etherington GJ, Ho SYW, Nash WJ, Grueber CE, Cheng Y, Whittington CM, Dennison S et al. 2018 Adaptation and conservation insights from the koala genome. Nature Genetics 50 1102-1111. (https://doi.org/10.1038/s41588-018-0153-5)

Lincoln DW \& Renfree MB 1981 Milk ejection in a marsupial Macropus agilis. Nature 289 504-506. (https://doi.org/10.1038/289504a0)

Pask AJ, Behringer RR \& Renfree MB 2008 Resurrection of DNA function in vivo from an extinct genome. PLoS ONE 3 e2240. (https://doi.org/10.1371/ journal.pone.0002240)

Pask AJ, Calatayud NE, Shaw G, Wood WM \& Renfree MB 2010 Oestrogen blocks the nuclear entry of SOX9 in the developing gonad of a marsupial mammal. BMC Biology 8 113. (https://doi.org/10.1186/1741-7007-8-113)

Renfree MB 1972 Influence of the embryo on the marsupial uterus. Nature 240 475-477. (https://doi.org/10.1038/240475a0)

Renfree MB 1979 Initiation of development of diapausing embryo by mammary denervation during lactation in a marsupial. Nature $278549-551$. (https://doi.org/10.1038/278549a0)

Renfree MB \& Fenelon JC 2017 The enigma of embryonic diapause. Development 144 3199-3210. (https://doi.org/10.1242/dev.148213)

Renfree MB \& McLaren A 1974 Foetal origin of transferrin in mouse amniotic fluid. Nature 252 159-161. (https://doi.org/10.1038/252159a0)

Renfree MB \& Shaw G 2000 Diapause. Annual Review of Physiology 62 353-375. (https://doi.org/10.1146/annurev.physiol.62.1.353)

Renfree MB \& Short RV 1988 Sex determination in marsupials: evidence for a marsupial-eutherian dichotomy. Philosophical Transactions of the Royal Society of London: Series B, Biological Sciences 322 41-53. (https://doi.org/10.1098/rstb.1988.0112)

Renfree MB, Lincoln DW, Almeida OFX \& Short RV 1981 Abolition of seasonal embryonic diapause in the tammar wallaby by sympathetic denervation of the pineal gland. Nature 293 138-139. (https://doi.org/10.1038/293138a0)

Renfree MB, Hore TA, Shaw G, Graves JAM \& Pask AJ 2009 Evolution of genomic imprinting: insights from marsupials and monotremes. Annual Review of Genomics and Human Genetics 10 241-262. (https://doi.org/10.1146/annurev-genom-082908-150026)

Renfree MB, Papenfuss AT, Deakin JE, Lindsay J, Heider T, Belov K, Rens W, Waters PD, Pharo EA, Shaw G et al. 2011 Genome sequence of an Australian kangaroo, Macropus eugenii, provides insight into the evolution of mammalian reproduction and development. Genome Biology 12 R81. (https://doi.org/10.1186/gb-2011-12-8-r81)

Renfree MB, Suzuki S \& Kaneko-Ishino T 2013 The origin and evolution of genomic imprinting and viviparity in mammals. Philosophical Transactions of the Royal Society of London: Series B, Biological Sciences 368 20120151. (https://doi.org/10.1098/rstb.2012.0151)

Shaw G, Renfree MB, Leihy MW, Shackleton HL, Roitman E \& Wilson JD 2000 Prostate formation in a marsupial is mediated by the testicular androgen $5 \alpha$-androstane-3 $\alpha, 17 \beta$-diol. PNAS 97 12256-12259.

Short WS, Renfree RV, Shaw G \& Shaw G 1988 Primary genetic control of somatic sexual differentiation in a mammal. Nature 331 716-717. (https:// doi.org/10.1038/331716a0)

Short RV, Lewis PR, Renfree MB \& Shaw G 1991 The contraceptive effects of extended periods of lactational amenorrhoea: beyond the Bellagio Consensus. Lancet 337 715-717. (https://doi.org/10.1016/0140-6736(91)90288-z)

Smits G, Mungall AJ, Griffiths-Jones S, Smith P, Beury D, Matthews L, Rogers J, Pask AJ, Shaw G, Vandeberg JL et al. 2008 Conservation of the H19 noncoding RNA and H19-IGF2 imprinting mechanism in therians. Nature Genetics 40 971-976. (https://doi.org/10.1038/ng.168)

Stringer JM, Suzuki S, Pask AJ, Shaw G \& Renfree MB 2012 Selected imprinting of INS in the marsupial. Epigenetics and Chromatin 5 14. (https:// doi.org/10.1186/1756-8935-5-14)

Suzuki S, Ono R, Narita T, Pask AJ, Alsop A, Shan E, Kohda WC, Shaw T, Graves G, Kohara Y et al. 2007 Retrotransposon silencing by DNA methylation can drive mammalian genomic imprinting. PLoS Genetics 3 e55.

Suzuki S, Shaw G \& Renfree MB 2013 Postnatal epigenetic reprogramming in the germ line of a marsupial, the tammar wallaby. Epigenetics and Chromatin 6 14. (https://doi.org/10.1186/1756-8935-6-14)

Suzuki S, Shaw G \& Renfree MB 2018 Identification of a novel antisense noncoding RNA, ALID, transcribed from the putative imprinting control region of marsupial IGF2R. Epigenetics and Chromatin 11 55. (https://doi.org/10.1186/s13072-018-0227-8)

Tyndale-Biscoe CH \& Renfree MB 1987 Reproductive Physiology of Marsupials, p. 476. Cambridge University Press.

Warren WC, LaDeana WH, Jennifer A, Graves M, Birney E, Ponting CP, Grutzner F, Belov K, Miller W, Clarke L et al. 2008. Genome analysis of the platypus reveals unique signatures of evolution. Nature 453 175-183.

Wilson JD, Auchus RJ, Leihy MW, Guryev OL, Estabrook RW, Osborn SM, Shaw G \& Renfree MB $20035 \alpha$-Androstane- $3 \alpha, 17 \beta$-diol is formed in tammar wallaby pouch young testes by a pathway involving $5 \alpha$-pregnane-3 $\alpha, 17 \alpha$-diol-20-one as a key intermediate. Endocrinology $144575-580$. (https://doi.org/10.1210/en.2002-220721) 


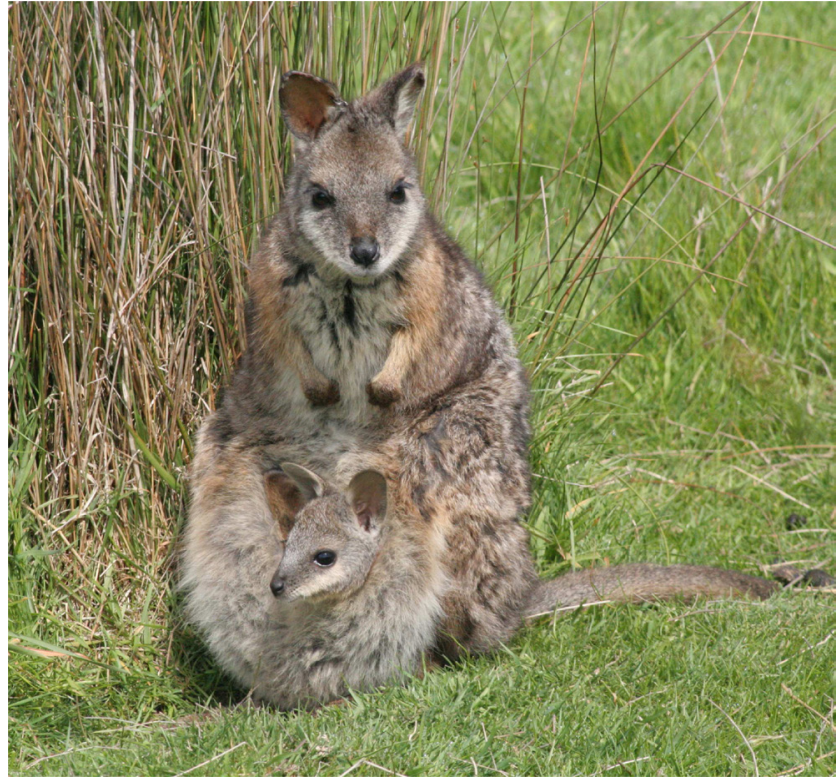

Figure 1 Tammar wallaby with her 9 month old pouch young, soon to leave the pouch.

an inflammatory effect (Renfree 1972). In the decades since, this has been amply confirmed and this observation extended (Renfree 2010), including the demonstration that the placenta is also hormone-secreting. As well as the incipient progesterone synthesis identified earlier (Heap et al. 1980), we now know the placenta produces prostaglandins $E_{2}$ and $F_{2 \alpha}$ (Shaw et al. 1999) as well as the pituitary hormones $\mathrm{GH}, \mathrm{GH}-\mathrm{R}, \mathrm{IGF}-2, \mathrm{PRL}$ and $\mathrm{LH} \beta$ (Menzies et al. 2011), in contrast to earlier dogma (Fig. 2).

Marsupial blastocysts have no inner cell mass, so we were intrigued as to how the trophoblast cells (that

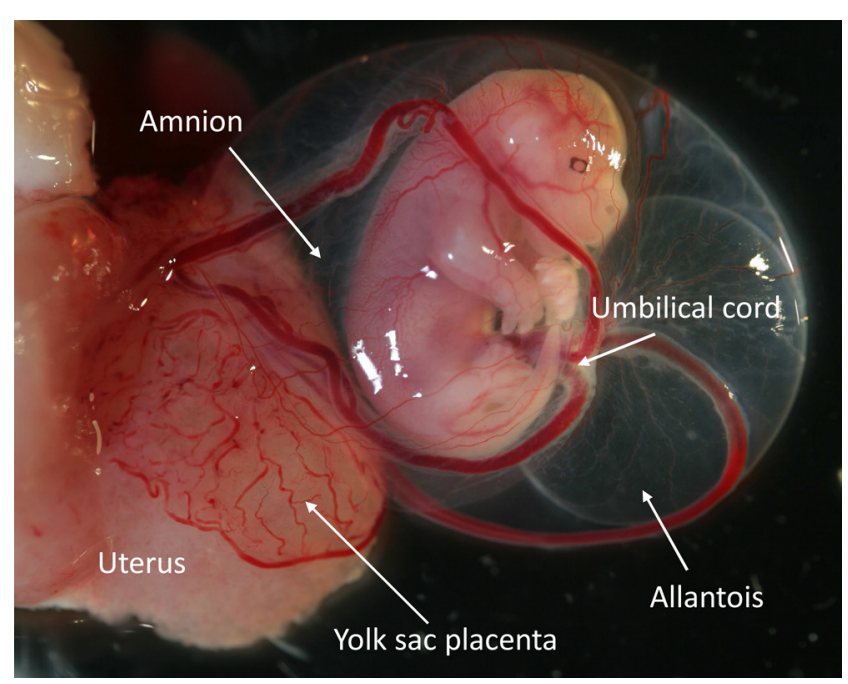

Figure 2 Tammar fetus and placenta. A full term fetus (day 25 of the 26.5 day pregnancy) still attached to the uterus and within its fetal membranes: the amnion, the allantois and the yolk sac (choriovitelline) placenta. will form the placenta) are differentiated from those cells that will form the embryo proper. Investigating the development of macropodid conceptuses from ovulation through cleavage stages to the early blastocyst in vivo and in vitro (Renfree \& Lewis 1996) did not tell us where on the single cell layered blastocyst the embryo would develop, but hinted at polarisation of the cells. Later studies using immunocytochemistry of the molecular analysis of mechanisms of early cell lineage specification in the wallaby showed us that while the same genes are involved in early development (e.g. POU5F1, CDX2, NANOG and GATA6), there is considerable evolutionary plasticity in the mechanisms regulating early lineage specification in mammals and marsupials differ markedly from mice in this regard for example the pluriblast-trophoblast differentiation coincided with a global nuclear-to-cytoplasmic transition of CDX2 localisation, and the Hippo pathway factors YAP and WWTR1 showed mutually distinct localisation patterns that suggest non-redundant roles (Frankenberg et al. 2010, 2013). In this way they may be more akin to the pattern seen in bovine embryos (Frankenberg et al. 2016).

\section{How do you stop an embryo growing and then start it again: the phenomenon of embryonic diapause}

Once in the blastocyst stage, some marsupial blastocysts have a hesitation in their development known as embryonic diapause. These are the kangaroos and wallabies, and the small possums including the feathertailed glider and the diminutive honey possum. In the tammar, over many years, Geoff Shaw and I and others, especially from Hugh Tyndale-Biscoe's lab. demonstrated the environmental and physiological signals for entry into and exit from diapause (reviewed in Renfree \& Shaw 2000, Renfree \& Fenelon 2017). These include melatonin, mediated by photoperiod beginning on the longest day, prolactin, that inhibits the growth of the corpus luteum, and progesterone that reactivates the secretory endometrium and blastocyst. We always knew lactation and the sucking stimulus was a key factor, but I decided to do some heroic surgery to test this by removing all neural signals from the teat while allowing lactation to continue. The results were unequivocal: it is neural inputs from the teat that control lactational embryonic diapause in marsupials (Renfree 1979). This work provided the background for our extensive study (with my husband Roger Short and Geoff Shaw) on the contraceptive effects of breastfeeding in women, reinforcing the idea that breastfeeding is Nature's contraceptive, even in women (Short et al. 1991).

To investigate the proximal signals for the seasonal diapause, I made another difficult surgical approach. Removal of the superior cervical ganglion, that lies right on top of the internal carotid artery, showed the sympathetic innervation of the pineal gland controls 
melatonin secretion and in turn the remarkable highly synchronised reactivation from seasonal diapause in the tammar wallaby that occurs on the longest day in the Southern hemisphere, December 22nd (Renfree et al. 1981). An even more difficult surgical approach - pinealectomy - by Steve McConnell in Hugh TyndaleBiscoe's lab gave the same result (McConnell \& Hinds 1985, Tyndale-Biscoe et al. 1986). Thus melatonin is critical for the control of seasonal breeding, as it is also in the red deer (Lincoln \& Short 1980, Lincoln et al. 1984). These results from two very different species gave Roger the idea that melatonin might ameliorate jet lag (Short 1993), an idea that he subsequently proved and for which he held the use patent - now used all over the world for jet lag, including for shift workers and astronauts.

\section{Conception and contraception}

While more and more marsupials are becoming extinct due to human clearing of habitat and climate change, there are some species that are overabundant. Roger had a friend and colleague in the company 'Leiras' in Finland, who marketed a levonorgestrel contraceptive implant. When they were taken over, Roger obtained a number of their implants. With Geoff Shaw, Kath Handasyde and our students, we used these to reversetranslate this human contraceptive into an effective management tool for overabundant populations of kangaroos (Nave et al. 2000, 2002) and koalas (Hynes et al. 2011), now being used in the field for management of overabundant koalas by State authorities. On the flip side, my lab developed assisted reproductive techniques for marsupials, including the first in vitro fertilised marsupial embryo (Richings et al. 2004), the first conceptus produced by artificial insemination (AI) (Paris et al. 2005) and the first maturation of follicles in vitro after cold storage (Richings et al. 2006). Injection through the shell coat that surrounds all marsupial conceptuses was challenging, as was attempting Al via the long median vagina of marsupials. In the end, Al success was only achieved by bypassing the median and lateral vaginae (marsupials have three vaginae) and injection into the uterine cavity (Paris et al. 2005).

\section{Can milk composition control growth? Lactation and growth acceleration}

Marsupials have the remarkable ability to alter the composition of their milk in tune with the growth of the young. Some continuously-breeding macropodid marsupials have concurrent, asynchronous lactation, in which a new tiny young is drinking milk of a different composition from that of its older sibling ('young-at-foot') (Green et al. 1980, Nicholas 1998, Nicholas et al. 1997). How the marsupial teat and mammary gland behaves independently from the adjacent teat to synthesise milks of different composition depending upon the age of the pouch young has been a key question in lactational biology. We established that the neuroendocrine control of milk ejection in marsupials by oxytocin differs between these glands (Lincoln \& Renfree 1981a,b), and it appears to be an aging phenomenon of the gland and not related to the sucking stimulus (Trott et al. 2003). This means that there is a strong the maternal control of pouch young growth. We exploited this to show the effects of providing different milk compositions at different stages of growth. We fostered young from an early stage of lactation to a more advanced stage of lactation and caused an astonishingly rapid growth acceleration with early maturation and shortened time to pouch exit and independence of the young (Trott et al. 2003, Menzies et al. 2007, Hetz et al. 2015). Interestingly, the marsupial mammary gland and placenta share 77 genes with the early-mid eutherian placenta. These genes (e.g. GATA3, $M S H 2$, and GCM1) are associated with nutrient transport (Guernsey et al. 2017) - demonstrating again the importance of lactation and maternal control of growth during development - marsupials have truly traded the umbilical cord for the teat.

\section{The development of males and females: sexual differentiation}

The long post-natal period of development provided a unique opportunity to understand how hormones, genes and signalling molecules control sex determination and sexual differentiation. Pondering over some scanning electron micrographs, I serendipitously observed that there were scrotal bulges in the embryo before the differentiation of the testis and production of testosterone. I called Roger to tell him what I had seen. He was immediately sceptical! I determined to show that marsupials really did differentiate their scrotum before they have functional testes capable of synthesising testosterone. Geoff Shaw had recently returned to my lab and with our sabbatical visitor, Dr Wai-Sum O and Roger we established that these structures were hormone-independent and that there was indeed a direct genetic control by a gene or genes on the $\mathrm{X}$ chromosome (O et al. 1988, Renfree \& Short 1988, Fig. 3). This novel finding has been amply confirmed and has directed research from multiple laboratories to an entirely new and expanding field of investigation. Direct $X$ and $Y$ chromosome effect, (and Z/W effects in birds), have now been demonstrated in eutherian mammals, particularly in mice, and almost certainly in humans (Arnold 1997, Burgoyne et al. 2001, Arnold \& Burgoyne 2004, Renfree et al. 2014).

These studies overturned entrenched dogma and the Jost paradigm of hormonally-controlled sexual differentiation in all mammals (O et al. 1988, Renfree \& Short 1988, Shaw et al. 1988). We demonstrated that these sexually dimorphic characters differentiate 

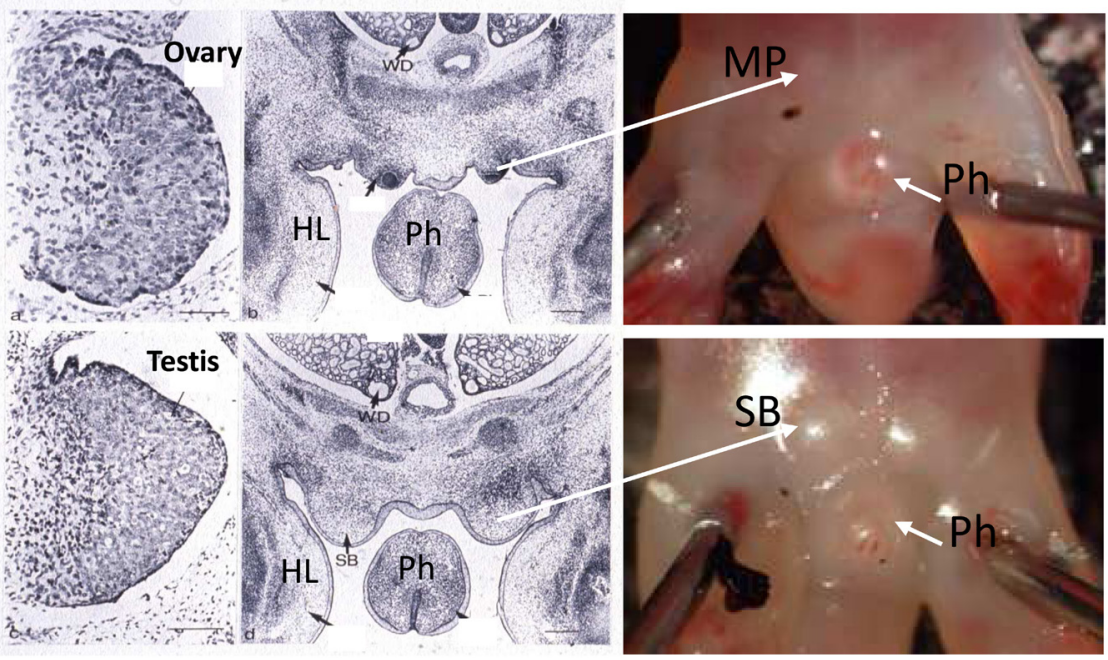

Figure 3 Fetal gonads and developing scrotum and pouch. Some sexual dimorphisms (namely the scrotum and the mammary glands) are controlled by genes on the $X$ chromosome and differentiate before the testis begins secreting androgens. Female fetuses at day 25 of gestation, 1.5 days before birth have indifferent gonads (top, left hand panel) but have already developed paired mammary primordia (MP; top, middle panel), while males have indifferent gonads (bottom left hand panel) yet have paired scrotal bulges (SB; bottom, middle and right hand panel. The phallus $(\mathrm{Ph})$ is likewise not yet sexually dimorphic and the hind limbs $(\mathrm{HL})$ are merely a paddle. WD: Wolffian duct. Redrawn from Renfree et al. (1996). independently of hormones, and we went on to show that these are linked to X-chromosome dosage. At about the same time, we discovered that we could induce testis-to-ovary sex reversal with exogenous oestrogen (Coveney et al. 2001), the first demonstration of oestrogen-induced gonadal sex reversal in any mammal. Surprisingly, we sex reversed not only the somatic cells but also the germ cells after oral treatment with oestrogen alone. This led on to our demonstration with Andrew Pask, then a research fellow in my lab, that oestrogen prevents the nuclear shuttling of SOX9 (Pask et al. 2010), suggesting a mechanism by which oestrogens are necessary to help to maintain ovarian development in other mammals, and how environmental oestrogen analogues might contribute to sex reversal in amphibians and the decline of male fertility in humans. Understanding how environmental oestrogen analogues contribute to sex reversal and the decline of male fertility coupled with increase in the frequency of disorders of sex development in humans is critical to understand the role of environmental endocrine disruptors (EEDS) in development. We are now using this marsupial model to investigate EEDs (see end of text).

Another serendipitous event led me to the next phase of our studies on sexual differentiation. I was fortunate that a famous endocrinologist, Jean D Wilson (from University of Texas Medical School in Dallas) was visiting Monash just after he had published a paper on gonadal steroids in the North American opossum (George et al. 1985). In conversation, I asked Jean if he might be interested in the tammar, and so began a thirty-year collaboration that continues to this day. We puzzled over the fact that the timing of the virilisation of structures of the male reproductive system in marsupials could not be accounted for by the classical pathways producing testosterone and dihydrotestosterone. After many hours in the wallaby yards, much fine dissection, numerous incubations with radioactive steroids and the help of Jean's Dallas colleagues with
HPLC, Jean, Geoff Shaw and I identified a previously unrecognised androgen biosynthetic pathway that forms dihydrotestosterone via an alternate pathway in which the potent androgen androstanediol is the key circulating androgen. This alternate pathway appears to be essential for the development of normal male tammars as well as mouse and man (Shaw et al. 2000, Leihy et al. 2001, Wilson et al. 2003). It has been translated into a new clinical guideline by the US Endocrine Society and has again spawned a whole new field of clinical studies (Arlt et al. 2004, Homma et al. 2006, Fluck et al. 2011, Fukami et al. 2013, Reisch et al. 2013, Marti et al. 2017, Speiser et al. 2018). It explains the virilisation seen in girls with P450 oxidoreductase deficiency (Arlt et al. 2004, Homma et al. 2006) and explains virilisation of female infants with 21-hydroxylase deficiency (Reisch et al. 2013). Burgeoning international studies of this pathway now implicate the alternate pathway not only in sexual development, but also is implicated in the hyperandrogenism seen in polycystic ovarian syndrome (Marti et al. 2017).

In more recent studies, again using a surgical approach in which I transplanted gonads from the neonatal male tammar under the skin of female tammars, we induced a penis-like phallus in females and after castration, early post-natal male young developed a phallus with an open urethral canal, providing a model for hypospadias. Hypospadias is the second most common birth defect occurring in 1:125 boys in the Western world and is increasing in frequency (Kalfa et al. 2010, 2011), so marsupials provide a unique model for understanding this increasingly common disorder of sex differentiation. Because these critical phases of phallus development occur after birth of the pouch young in marsupials, they can be readily manipulated, unlike in eutherian embryos that complete these stages in utero. Our most recent studies are now investigating the effects of oestrogens as well as androgens on phallus development. 


\section{Transcriptomics}

In recent years we have completed a new genome of the tammar wallaby that has a $200 \times$ coverage. While it is yet to be published, the new genome does include over 150 transcriptomes of various reproductive tissues, including an amazing set of transcriptome data completed for us by Prof. Asao Fujiyama and his colleagues at the National Institute of Informatics and the National Institute of Genetics in Japan of the developing phallus after we treated the young with androgens, oestrogens and after castration. These data have shown us just how sensitive the genes of the developing phallus are to exogenous androgens and oestrogens, highlighting their steroid hormone sensitivity (Chew et al. 2014, Chen et al. 2018a,b). Furthermore, there are hundreds of long non-coding genes (IncRNAS) that are also up-or down-regulated by the steroid treatments, apparently in concert with their coding genes (Chen et al. 2019). LncRNAs have conserved functions, but do not have conserved sequences between mammals, so they are often difficult to fully characterise. Nevertheless it is clear that both coding and non-coding genes could be direct targets of exogenous hormones, and underpins many of the effects observed with EEDS. With research fellow Gerard Tarulli we are now investigating the relative importance of the androgens, oestogens and their inhibitors on phallus differentiation.

\section{Father's influence on the offspring: genomic imprinting}

In 1996, I was fortunate to be one of only two Australians to be invited to attend the award of the Japan prize to Prof. Ryuzo Yanagamachi. At the symposium that followed the award ceremony (where I met and spoke with Emperor Akihito), I met a young Japanese scientist (Dr, now Professor) Fumi Ishino, who had a very interesting poster on genomic imprinting in mice. Genomic imprinting results from a parent-of-origin mark (usually methylation) on certain genes, many of which appear to control growth of the fetus. Our discussion around Fumi's poster led to a $22+$ year ongoing collaboration on marsupial genomic imprinting, first focusing on the placentallyimprinted genes and developing new concepts on the evolution of imprinting. With these wonderful Japanese colleagues and research fellow Shunsuke Suzuki, we showed that retrotransposon insertion could drive the acquisition of imprinting in mammalian evolution via differential methylation, proving for the first time that a differentially methylated region (DMR) also occurred in marsupials, contrary to the assumptions of the time (Suzuki et al. 2007). A second marsupial gene with a DMR resulted from collaboration with Wolf Reik's laboratory at Babraham UK where Guillaume Smits identified the first ncRNA (H19) in the tammar wallaby (Smits et al. 2008). We also began collaborating with another key Cambridge imprinting laboratory, that of Anne Ferguson-Smith that continues today. We have now examined 14 genes that are imprinted in the eutherian placenta in the marsupial placenta, but of these only 8 are imprinted, and only three have a DMR (PEG10, H19 and IGF2R) (Renfree et al. 2013, Suzuki et al.2018).

Postgraduate students working in our lab were able to visit the Ishino and the Ferguson-Smith labs and vice versa. This has been a wonderful unexpected consequence of these collaborations. We identified genomic imprinting of insulin and IGF2 in the tammar placenta, and another surprising finding was that these two genes are imprinted in the marsupial mammary gland and pouch young post-natally, reinforcing the parallels between eutherian placentation and marsupial nutritional control via lactation. Most recently, continuing our collaboration with Shunsuke Suzuki we showed that there is a IncRNA (ALID) in the marsupial IFG $2 R$ locus. This gene is the best candidate factor for establishing the paternal silencing of marsupial IGF2R but without the transcriptional overlap that occurs in the mouse Ifg2r locus with its IncRNA Airn (Suzuki et al. 2018). The tammar also shares the same process of global methylation of germ cells as other mammals, although as expected, the timing differs, being postnatal in the tammar and pre-natal in eutherians (Ishihara et al. 2019).

All this from a chance encounter at an international conference!

\section{Australian Mammal Genomes}

In a parallel universe, Jenny Graves (then at La Trobe University in Melbourne) had spent much of her career working on marsupial chromosomes. Our work first intersected during the search for the sex-determining gene in mammals. Jenny asked me if I could provide her with some marsupial tissue. I gladly did so, not realising it would lead to another amazing long term and productive collaboration. These tissues helped show that the $Z F Y$ gene was NOT the marsupial sex determining gene and led to the identification of $S R Y$ in marsupials (Foster et al. 1992). Later, Jenny invited me, Peter Temple-Smith and others to propose the construction of the platypus genome to NIH. This bid was successful, and led to an important paper (Warren et al. 2008). Sadly, when we tried to get $\mathrm{NIH}$ funding for the first marsupial genome of the tammar wallaby, we were pipped at the post by colleagues in the US who made a case for the South American opossum genome as an 'American' marsupial. The opossum genome was therefore the first marsupial genome sequenced and assembled. In response, Jenny and I proposed and were awarded an ARC Centre of Excellence ( $\mathrm{C}$ of $\mathrm{E}$ ) grant in Kangaroo Genomics (KanGO) (though with reduced funding to the other centres, so we called it the 'Centre of Very Goodness'!). This was a fantastic collaborative effort with the late 
Professor Des Cooper from Macquarie University, and Partner investigators Dr Sue Forrest (Australian Genome Research Facility) and Prof Terry Speed of the Walter and Eliza Hall Institute of Medical Research, with some 50 investigators. Jenny led KanGO for the first 5 years, and I led for the last three. The 8 years funding allowed us to make huge leaps and bounds in the field of comparative genomics. We succeeded in getting the tammar genome published as the first Australian marsupial genome, largely as a result of this $C$ of $E$ (Renfree et al. 2011). We now have additional marsupial genomes - the Tasmanian devil (Murchison et al. 2012) and the koala (Johnston et al. 2018). Andrew Pask has just published the extinct Tasmanian Tiger genome (Feigin et al. 2018; see more below) and the dunnart genome is virtually finished (AJ Pask, MB Renfree and SR Frankenberg, unpublished results). We are currently working on updating the platypus genome and including the echidna genome, led by Guojie Zhang.

We used comparative genomic approaches to define the developmental processes common to all mammals and to identify the genes conserved among the monotreme, marsupial, and eutherian genomes. From our genome studies we now know that marsupials provide a suite of essential mammalian characteristics - controlling pregnancy, placentation, lactation and sex determination and differentiation including the $S R Y$ gene that is critical for testis and subsequently brain development - to help understand the mammalian genome, including the human genome. However, the monotremes continue to fascinate and confound, with their multiple chromosome (5Xs and $5 \mathrm{Ys}$ : platypus and $5 \mathrm{Xs}$ and $4 \mathrm{Ys}$ : echidna) and their lack of the male sex-determining gene SRY. These studies have shed light on the evolution of mammalian reproduction and development.

\section{Extinct and threatened mammals: Tasmanian tigers and elephants}

My colleague, Joan Dixon at the Museum Victoria who was curator of mammals allowed me to sample some of the extinct thylacine pouch young samples that were in the Museum. I took the tissue to Texas to Richard Behringer's laboratory, where several years later Andrew Pask cloned a regulatory sequence from the Col2a gene from this extinct marsupial, and Richard Behringer then made the transgenic mouse where it gave appropriate expression. This was the first example of the expression of a gene from an extinct animal into a living organism (the mouse embryo). This proof of principle study (Pask et al. 2008) generated great international interest since it presages a way of bringing the genes of extinct species 'back to life'.

Using another iconic mammal, we had the good fortune to obtain a series of 10 embryos and fetuses of the African elephant resulting from a cull at Kruger

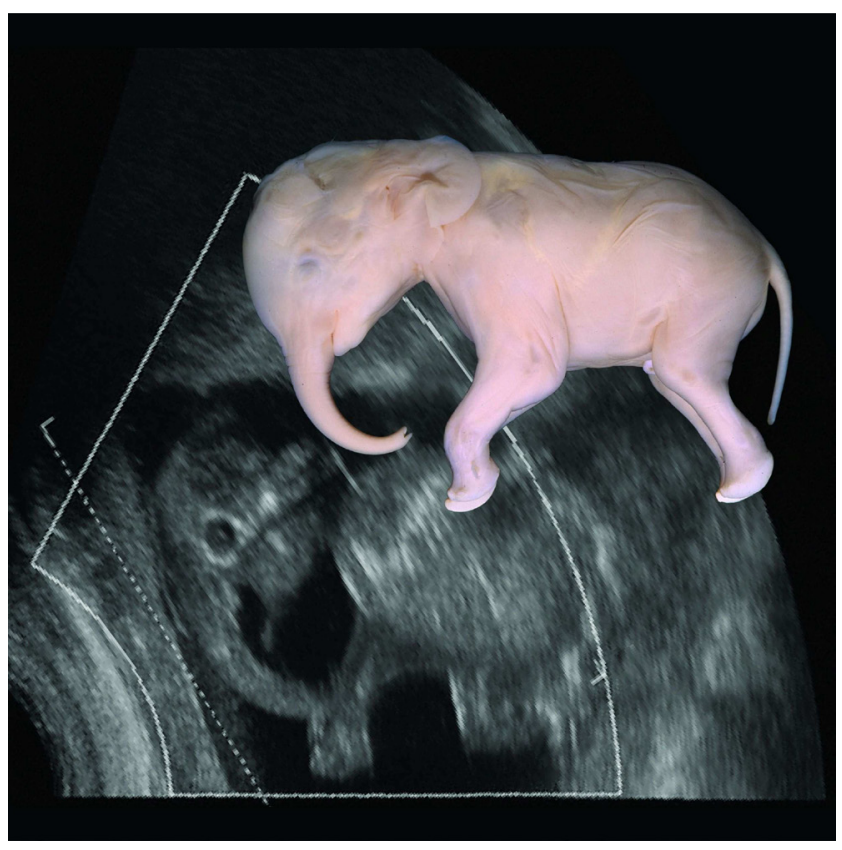

Figure 4 Elephant development. Gestation of the elephant is 22 months. This fetus is 167 days old, shown with an ultrasound image of a similar aged fetus in utero. Crown-rump-length of the fetus was $150 \mathrm{~mm}$. Based on images from Hildebrandt et al. (2007). With thanks to Prof. Geoff Shaw for creating the montage.

National Park. With our postgraduate student (Gaeth et al.1999) (Fig. 4) we described the early development of these embryos. A surprising observation was that these fetuses had nephrostomes in the developing embryo mesonephric kidneys, confirming the palaeontological conclusions that elephants have an aquatic origin of elephants. Putting the detailed anatomy together with the amazing ultrasound images of our colleague from Berlin, Prof. Thomas Hildebrandt, we continued the study and provided the first (and still the only) accurate growth curves of any elephant during the first trimester of the 22 month pregnancy (Hildebrandt et al. 2007).

\section{A prickly problem}

With the help and support of Queensland's Currumbin Wildlife Sanctuary (Gold Coast) and Steve Johnston at University of Queensland and our research fellow Jane Fenelon, we have now embarked on the world's first morphological and molecular study of the complete development of the echidna embryo (from egg-laying, when the embryo is at the early somite stage to the newly hatched egg 10 days later) and the early stage pouch young, as well as a detailed study of the adult reproductive physiology and endocrinology. Currumbin have created a small breeding colony (Wallage et al. 2015) and have partnered with us to study these remarkable animals, a unique opportunity to learn about the reproduction and development of these egg-laying mammals, the 


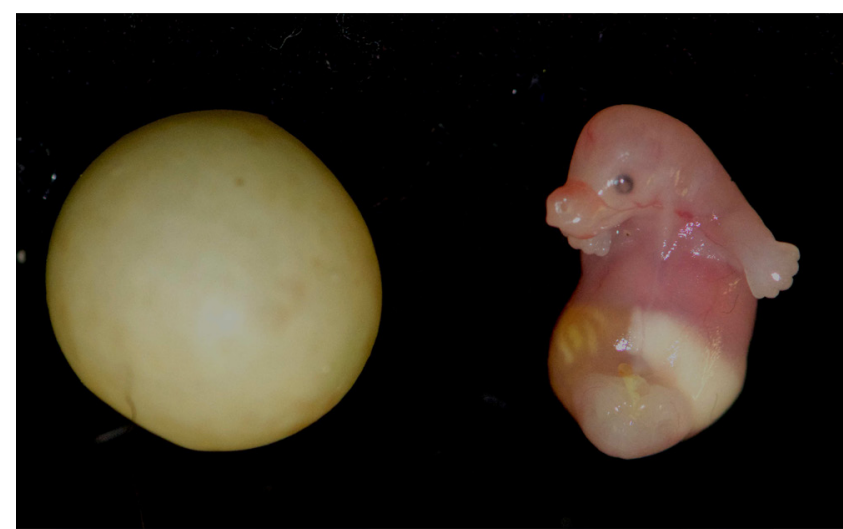

Figure 5 An echidna young and its egg. A newly hatched echidna pouch young and the leathery egg from which it hatched (to the same scale). The diameter of the egg is $15-16 \mathrm{~mm}$ - about the same size as an Australian 5 cent piece that also features the echidna!

Monotremata. This monotreme (one of the two types of egg-laying mammals) is abundant in Australia, but until very recently the echidna had rarely been bred in captivity. After 18 days of in utero development, the young hatches from a leathery egg with the help of an egg tooth on the upper jaw and a caruncle on their nose (Fig. 5). The stage of development at hatching, with its altricial body, well developed fore-limbs and hind limbs that are just limb paddles, is morphologically remarkably like the stage of development reached by a new-born tammar wallaby. However, as their name implies, they differ from therian mammals in having only one exterior opening, the cloaca, for all their reproductive and excretory activities.

\section{Next steps}

Future research will use many different model species as it is increasingly recognised that there is no one model that will answer questions about human reproduction. Marsupials will surely be amongst them with their delayed post-natal development that provides access to development that only occurs in utero in us and other eutherian mammals. We are increasingly exposed to multiple chemical and compounds in the environment. These environmental endocrine disruptors (EEDs) are a pressing problem for reproduction not only in mammals but in most other species and including fish and amphibians. Transgenerational effects of these EEDs are also an increasing concern. Infertility and errors like hypospadias are increasing in men and boys respectively. We need to change government policy on the use of compounds now known to be environmental toxins, especially in the face of additional disruption from climate change. And then there is the enigma of embryonic diapause! How exciting if we could discover the molecular signals that put that embryo to sleep, and wake it up, and maybe there will be factors that might help us control cell growth in other areas where cell stasis will be critical, including cancer. Reproduction is a wonderful field in which to do research - as Roger always says, 'Reproduction is the science of the transmission of life. What could be more important than that!'.

\section{Conclusion}

My studies have incorporated very many diverse biological and biomedical questions, in some cases establishing new fields of research. Providing new insights through the study of the unique evolutionary innovations in the reproductive systems of marsupials and monotremes has been challenging, but there is no doubt that study of these remarkable animals still has so much to tell us about ourselves and the world in which they evolved. All this work was a result of amazing collaborations and hard work of my colleagues, students and research fellows - without them progress would have ground to a halt and it would not have been as much fun as it has been and continues to be.

\section{Declaration of interest}

The author declares that there is no conflict of interest that could be perceived as prejudicing the impartiality of this review.

\section{Funding}

This work was supported by numerous research project grants for over four decades from the National Health and Medical Research Council and the Australian Research Council including a Federation Fellowship and a Centre of Excellence grant.

\section{References}

Arlt W, Walker EA, Draper N, Ivison HE, Ride JP, Hammer F, Chalder SM, Borucka-Mankiewicz M, Hauffa BP, Malunowicz EM et al. 2004 Congenital adrenal hyperplasia caused by mutant P450 oxidoreductase and human androgen synthesis: analytical study. Lancet 363 2128-2135. (https://doi.org/10.1016/S0140-6736(04)16503-3)

Arnold AP 1997 Sexual differentiation of the zebra finch song system: positive evidence, negative evidence, null hypotheses, and a paradigm shift. Journal of Neurobiology 33 572-584. (https://doi.org/10.1002/ (SICI)1097-4695(19971105)33:5<572::AID-NEU6>3.0.CO;2-1)

Arnold AP \& Burgoyne PS 2004 Are XX and XY brain cells intrinsically different? Trends in Endocrinology and Metabolism 15 6-11. (https://doi. org/10.1016/j.tem.2003.11.001)

Burgoyne PS, Lovell-Badge R \& Rattigan A 2001 Evidence that the testis determination pathway interacts with a non-dosage compensated, X-linked gene. International Journal of Developmental Biology 45 509512.

Chen Y, Yu H, Pask AJ, Fujiyama A, Suzuki Y, Sugano S, Shaw G \& Renfree MB 2018a Hormone-responsive genes in the SHH and WNT/ $\beta$ catenin signalling pathways influence urethral closure and phallus growth. Biology of Reproduction 99 806-816. (https://doi.org/10.1093/ biolre/ioy 117)

Chen Y, Yu H, Pask AJ, Fujiyama A, Suzuki Y, Sugano S, Shaw G \& Renfree MB 2018b Effect of androgen and oestrogen on IGF pathways controlling phallus growth. Reproduction 157 1-12. (https://doi. org/10.1530/REP-18-0416) 
Chen Y, Yu H, Pask AJ, Toyoda A, Fujiyama A, Shaw G \& Renfree MB 2019 Androgen and oestrogen affect the expression of long non-coding RNAs during phallus development in a marsupial. Non-Coding RNA 5 E3. (https://doi.org/10.3390/ncrna5010003)

Chew KY, Pask AJ, Hickford D, Shaw G \& Renfree MB 2014 A dual role for SHH in phallus development. Sexual Development 8 166-177. (https:// doi.org/10.1159/000357927)

Coveney D, Shaw G \& Renfree MB 2001 Estrogen-induced gonadal sex reversal in the tammar wallaby. Biology of Reproduction 65 613-621. (https://doi.org/10.1095/biolreprod65.2.613)

Feigin CY, Newton AH, Doronina L, Schmitz J, Hipsley CA, Mitchell KJ, Gower G, Llamas B, Soubrier J, Heider TN et al. 2018 Genome of the Tasmanian tiger provides insights into the evolution and demography of an extinct marsupial carnivore. Nature Ecology and Evolution 2182 192. (https://doi.org/10.1038/s41559-017-0417-y.

Fluck CE, Meyer-Boni M, Pandey AV, Kempná P, Miller WL, Schoenle EJ \& Biason-Lauber A 2011 Why boys will be boys: two pathways of fetal testicular androgen biosynthesis are needed for male sexual differentiation. American Journal of Human Genetics 89 201-218. (https://doi.org/10.1016/j.ajhg.2011.06.009)

Foster JW, Brennan FE, Hampikian GK, Goodfellow PN, Sinclair AH, Lovell-Badge R, Selwood L, Renfree MB, Cooper DW \& Marshall Graves JA 1992 Evolution of sex determination and the Y chromosome: SRY-related sequences in marsupials. Nature 359 531-533. (https://doi. org/10.1038/359531a0)

Frankenberg S, Pask AJ \& Renfree MB 2010 The evolution of class V POU domain transcription factors in vertebrates and their characterisation in a marsupial. Developmental Biology 337 162-170. (https://doi. org/10.1016/j.ydbio.2009.10.017)

Frankenberg SR, Shaw G, Freyer C, Pask AJ \& Renfree MB 2013 Early cell lineage specification in a marsupial: a case for diverse mechanisms among mammals. Development 140 965-975. (https://doi.org/10.1242/ dev.091629)

Frankenberg SR, de Barros FRO, Rossant J \& Renfree MB 2016 The mammalian blastocyst. Wiley Interdisciplinary Reviews: Developmental Biology 5 210-232. (https://doi.org/10.1002/wdev.220)

Fukami M, Homma K, Hasegawa T \& Ogata T 2013 Backdoor pathway for dihydrotestosterone biosynthesis: implications for normal and abnormal human sex development. Developmental Dynamics 242 320-329. (https://doi.org/10.1002/dvdy.23892)

Gaeth AP, Short RV \& Renfree MB 1999 The developing renal, reproductive, and respiratory systems of the African elephant suggest an aquatic ancestry. PNAS 96 5555-5558. (https://doi.org/10.1073/ pnas.96.10.5555)

George FW, Hodgins MB \& Wilson JD 1985 The synthesis and metabolism of gonadal steroids in pouch young of the opossum, Didelphis virginiana. Endocrinology 116 1145-1150. (https://doi.org/10.1210/endo-116-31145)

Green B, Newgrain K \& Merchant J 1980 Changes in milk composition during lactation in the tammar wallaby (Macropus eugenii). Australian Journal of Biological Sciences 33 35-42. (https://doi.org/10.1071/ B19800035)

Guernsey W, Chuong EB, Cornelis G, Renfree MB \& Baker JC 2017 Molecular conservation of marsupial and eutherian placentation and lactation. eLife 6 e30994. (https://doi.org/10.7554/eLife.30994)

Heap RB, Renfree MB \& Burton RD 1980 Steroid metabolism in the yolk sac placenta and endometrium of the tammar wallaby, Macropus eugenii. Journal of Endocrinology 87 339-349. (https://doi.org/10.1677/ joe.0.0870339)

Hetz JA, Menzies BR, Shaw G, Rao A, Clarke IJ \& Renfree MB 2015 Growth axis maturation is linked to nutrition, growth and developmental rate. Molecular and Cellular Endocrinology 411 38-48. (https://doi. org/10.1016/j.mce.2015.04.009)

Hildebrandt T, Drews B, Gaeth AP, Goeritz F, Hermes R, Schmitt D, Gray C, Rich P, Streich WJ, Short RV et al. 2007 Foetal age determination and development in elephants. Proceedings: Biological Sciences $\mathbf{2 7 4}$ 323-331. (https://doi.org/10.1098/rspb.2006.3738)

Homma K, Hasegawa T, Nagai T, Adachi M, Horikawa R, Fujiwara I, Tajima T, Takeda R, Fukami M \& Ogata T 2006 Urine steroid hormone profile analysis in cytochrome P450 oxidoreductase deficiency: implication for the backdoor pathway to dihydrotestosterone. Journal of Clinical Endocrinology and Metabolism 91 2643-2649. (https://doi. org/10.1210/jc.2005-2460)
Hynes EF, Handasyde KA, Shaw G \& Renfree MB 2011 The effects of gestagen implants on the behaviour of free-ranging female koalas. Applied Animal Behaviour Science 134 209-216. (https://doi. org/10.1016/j.applanim.2011.06.019)

Ishihara T, Hickford D, Shaw G, Pask AJ \& Renfree MB 2019 DNA methylation dynamics in the germline of the marsupial tammar wallaby, Macropus eugenii. DNA Research 26 85-94. (https://doi.org/10.1093/ dnares/dsy040)

Johnston RN, O'Meally D, Chen Z, Etherington GJ, Ho SYW, Nash WJ, Grueber CE, Cheng Y, Whittington CM, Dennison S et al. 2018 Adaptation and conservation insights from the koala genome. Nature Genetics 50 1102-1111. (https://doi.org/10.1038/s41588-018-0153-5)

Kalfa N, Sultan C \& Baskin LS 2010 Hypospadias: etiology and current research. Urologic Clinics of North America 37 159-166. (https://doi. org/10.1016/j.ucl.2010.03.010)

Kalfa N, Philibert P, Baskin LS \& Sultan C 2011 Hypospadias: interactions between environment and genetics. Molecular and Cellular Endocrinology 335 89-95. (https://doi.org/10.1016/j.mce.2011.01.006)

Leihy MW, Shaw G, Wilson JD. \& Renfree MB 2001 Virilization of the urogenital sinus of the tammar wallaby is not unique to $5 \alpha$-androstane-

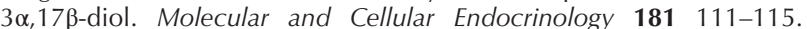
(https://doi.org/10.1016/S0303-7207(01)00527-5)

Lincoln DW \& Renfree MB 1981 a Milk ejection in a marsupial Macropus agilis. Nature 289 504-506. (https://doi.org/10.1038/289504a0)

Lincoln DW \& Renfree MB $1981 b$ Mammary gland growth and milk ejection in the agile wallaby, Macropus agilis, displaying concurrent asynchronous lactation. Journal of Reproduction and Fertility 63 193203. (https://doi.org/10.1530/jrf.0.0630193)

Lincoln GA \& Short RV 1980 Seasonal breeding: nature's contraceptive. Recent Progress in Hormone Research 36 1-52. (https://doi.org/10.1016/ b978-0-12-571136-4.50007-3)

Lincoln GA, Fraser HM \& Fletcher TJ 1984 Induction of early rutting in male red deer (Cervus elaphus) by melatonin and its dependence on LHRH. Journal of Reproduction and Fertility 72 339-343. (https://doi. org/10.1530/jrf.0.0720339)

Marti N, Galvan JA, Pandey AV, Trippel M, Tapia C, Muller M, Perren A \& Fluck CE 2017 Genes and proteins of the alternative steroid backdoor pathway for dihydrotestosterone synthesis are expressed in the human ovary and seem enhanced in the polycystic ovary syndrome. Molecular and Cellular Endocrinology 441 116-123. (https://doi.org/10.1016/j. mce.2016.07.029)

McConnell SJ \& Hinds LA 1985 Effect of pinealectomy on plasma melatonin, prolactin and progesterone concentrations during seasonal reproductive quiescence in the tammar, Macropus eugenii. Journal of Reproduction and Fertility 75 433-440. (https://doi.org/10.1530/jrf.0.0750433)

Menzies BR, Shaw G, Fletcher TP \& Renfree MB 2007 Perturbed growth and development in marsupial young after reciprocal cross-fostering between species. Reproduction, Fertility, and Development 19 976-983. (https://doi.org/10.1071/rd07142)

Menzies BR, Pask AJ \& Renfree MB 2011 Placental expression of pituitary hormones is an ancestral feature of therian mammals. EvoDevo 216. (https://doi.org/10.1186/2041-9139-2-16)

Murchison EP, Schulz-Trieglaff OB, Ning Z, Alexandrov LB, Bauer MJ, Fu B, Hims M, Ding Z, Ivakhno S, Stewart C et al. 2012 Genome sequencing and analysis of the Tasmanian devil and its transmissible cancer. Cell $\mathbf{1 4 8}$ 780-791. (https://doi.org/10.1016/j.cell.2011.11.065)

Nave CD, Shaw G, Short RV \& Renfree MB 2000 Contraceptive effects of levonorgestrel implants in a marsupial. Reproduction, Fertility, and Development 12 81-86. (https://doi.org/10.1071/rd00045)

Nave CD, Coulson G, Poiani A, Shaw G \& Renfree MB 2002 Fertility control in the eastern grey kangaroo using levonorgestrel implants. Journal of Wildlife Management 66 470. (https://doi.org/10.2307/3803180)

Nicholas KR 1988 Asynchronous dual lactation in a marsupial, the tammar wallaby (Macropus eugenii). Biochemical and Biophysical Research Communications 154 529-536. (https://doi.org/10.1016/0006291x(88)90172-6)

Nicholas K, Simpson K, Wilson M, Trott J \& Shaw D 1997 The tammar wallaby: a model to study putative autocrine-induced changes in milk composition. Journal of Mammary Gland Biology and Neoplasia 2299 310. (https://doi.org/10.1023/a:1026392623090)

O WS, Short RV, Renfree MB \& Shaw G 1988 Primary genetic control of somatic sexual differentiation in a mammal. Nature 331 716-717. (https://doi.org/10.1038/331716a0) 
Paris DB, Taggart DA, Shaw G, Temple-Smith PD \& Renfree MB 2005 Birth of pouch young after artificial insemination in the tammar wallaby (Macropus eugenii). Biology of Reproduction 72 451-459. (https://doi. org/10.1095/biolreprod.104.033282)

Pask AJ, Behringer RR \& Renfree MB 2008 Resurrection of DNA function in vivo from an extinct genome. PLOS ONE 3 e2240. (https://doi. org/10.1371/journal.pone.0002240)

Pask AJ, Calatayud NE, Shaw G, Wood WM. \& Renfree MB 2010 Oestrogen blocks the nuclear entry of SOX9 in the developing gonad of a marsupial mammal. BMC Biology 8 113. (https://doi.org/10.1186/1741-7007-8-113)

Reisch N, Högler W, Parajes S, Rose IT, Dhir V, Götzinger J, Arlt W \& Krone N 2013 A diagnosis not to be missed: nonclassic steroid $11 \beta$ hydroxylase deficiency presenting with premature adrenarche and hirsutism. Journal of Clinical Endocrinology and Metabolism 98 E1620E1625. (https://doi.org/10.1210/jc.2012-3449)

Renfree MB 1972 Influence of the embryo on the marsupial uterus. Nature 240 475-477. (https://doi.org/10.1038/240475a0)

Renfree MB 1979 Initiation of development of the diapausing embryo by mammary denervation during lactation in a marsupial. Nature $\mathbf{2 7 8} 549$ 551. (https://doi.org/10.1038/278549a0)

Renfree MB 2010 Marsupials: placental mammals with a difference. Placenta 31 (Supplement 1) S21-S26. (https://doi.org/10.1016/j. placenta.2009.12.023)

Renfree MB \& Fenelon JC 2017 The enigma of embryonic diapause. Development 144 3199-3210. (https://doi.org/10.1242/dev.148213)

Renfree MB \& Lewis AM 1996 Cleavage in vivo and in vitro in the marsupial Macropus eugenii. Reproduction, Fertility, and Development 8 725-742. (https://doi.org/10.1071/rd9960725)

Renfree MB \& Shaw G 2000 Diapause. Annual Review of Physiology 62 353-375. (https://doi.org/10.1146/annurev.physiol.62.1.353)

Renfree MB \& Short RV 1988 Sex determination in marsupials: evidence for a marsupial-eutherian dichotomy. Philosophical Transactions of the Royal Society of London: Series B, Biological Sciences 322 41-53. (https://doi.org/10.1098/rstb.1988.0112)

Renfree MB, Lincoln DW, Almeida OFX \& Short RV 1981 Abolition of seasonal embryonic diapause in the tammar wallaby by sympathetic denervation of the pineal gland. Nature 293 138-139. (https://doi. org/10.1038/293138a0)

Renfree MB, O WS, Short RV \& Shaw G 1996 Sexual differentiation of the urogenital system of the fetal and neonatal tammar wallaby, Macropus eugenii. Anatomy and Embryology 194 111-134.

Renfree MB, Papenfuss AT, Deakin JE, Lindsay J, Heider T, Belov K, Rens W, Waters PD, Pharo EA, Shaw G et al. 2011 Genome sequence of an Australian kangaroo, Macropus eugenii, provides insight into the evolution of mammalian reproduction and development. Genome Biology 12 R81. (https://doi.org/10.1186/gb-2011-12-8-r81)

Renfree MB, Suzuki S \& Kaneko-Ishino T 2013 The origin and evolution of genomic imprinting and viviparity in mammals. Philosophical Transactions of the Royal Society of London: Series B, Biological Sciences 368 20120151. (https://doi.org/10.1098/rstb.2012.0151)

Renfree MB, Chew KY \& Shaw G 2014 Hormone-independent pathways of sexual differentiation. Sexual Development 8 327-336. (https://doi. org/10.1159/000358447)

Richings NM, Shaw G, Temple-Smith PD \& Renfree MB 2004 Intracytoplasmic sperm injection in a marsupial. Reproduction 128 595-605. (https://doi.org/10.1530/rep.1.00270)

Richings NM, Shaw G, Temple-Smith PD \& Renfree MB 2006 Growth and histology of ovarian follicles after cold storage in the tammar wallaby. Reproduction, Fertility, and Development 18 677-688. (https://doi. org/10.1071/rd06007)

Shaw G, Renfree MB, Short RV \& O WS 1988 Experimental manipulation of sexual differentiation in wallaby pouch young treated with exogenous steroids. Development 104 689-701.

Shaw G, Gehring HM \& Bell EC 1999 Production of prostaglandin F2a and its metabolite by endometrium and yolk sac placenta in late gestation in the tammar wallaby, Macropus eugenii. Biology of Reproduction 60 611-614. (https://doi.org/10.1095/biolreprod60.3.611)

Shaw G, Renfree MB, Leihy MW, Shackleton CH, Roitman E \& Wilson JD 2000 Prostate formation in a marsupial is mediated by the testicular androgen $5 \alpha$-androstane-3 $\alpha, 17 \beta$-diol. PNAS 97 12256-12259. (https:// doi.org/10.1073/pnas.220412297)

Short RV 1993 Melatonin. Hormone of darkness. BMJ 307 952-953. (https://doi.org/10.1136/bmj.307.6910.952)

Short RV, Lewis PR, Renfree MB \& Shaw G 1991 Contraceptive effects of extended periods of lactational amenorrhoea: beyond the Bellagio Consensus. Lancet 337 715-717. (https://doi.org/10.1016/01406736(91)90288-z)

Smits G, Mungall AJ, Griffiths-Jones S, Smith P, Beury D, Matthews L, Rogers J, Pask AJ, Shaw G, Vandeberg JL et al. 2008 Conservation of the H19 noncoding RNA and H19-IGF2 imprinting mechanism in therians. Nature Genetics 40 971-976. (https://doi.org/10.1038/ng.168)

Speiser PW, Arlt W, Auchus RJ, Baskin LS, Conway GS, Merke DP, Meyer-Bahlburg HFL, Miller WL, Murad MH, Oberfield SE et al. 2018 Congenital adrenal hyperplasia due to steroid 21-hydroxylase deficiency: an Endocrine Society Clinical Practice Guideline. Journal of Clinical Endocrinology and Metabolism 95 4133-4160. (https://doi. org/10.1210/jc.2009-2631)

Suzuki S, Ono R, Narita T, Pask AJ, Alsop AE, Shan WC, Kohda T, Shaw G, Graves JA, Kohara Y et al. 2007 Retrotransposon silencing by DNA methylation can drive mammalian genomic imprinting. PLoS Genetics 3 e55. (https://doi.org/10.1371/journal.pgen.0030055)

Suzuki S, Shaw G \& Renfree MB 2018 Identification of a novel antisense noncoding RNA, ALID, transcribed from the putative imprinting control region of marsupial IGF2R. Epigenetics and Chromatin 11 55. (https:// doi.org/10.1186/s13072-018-0227-8)

Trott JF, Simpson KJ, Moyle RL, Hearn CM, Shaw G, Nicholas KR \& Renfree MB 2003 Maternal regulation of milk composition, milk production, and pouch young development during lactation in the tammar wallaby (Macropus eugenii). Biology of Reproduction 68929 936. (https://doi.org/10.1095/biolreprod.102.005934)

Tyndale-Biscoe CH \& Renfree MB 1987 Reproductive Physiology of Marsupials, p. 476. Cambridge University Press.

Tyndale-Biscoe CH, Hinds LA \& McConnell SJ 1986 Seasonal breeding in a marsupial: opportunities of a new species for an old problem. Recent Progress in Hormone Research 42 471-512. (https://doi.org/10.1016/ b978-0-12-571142-5.50015-x)

Wallage A, Clarke L, Thomas L, Pyne M, Beard L, Ferguson A, Lisle A \& Johnston S 2015 Advances in the captive breeding and reproductive biology of the short-beaked echidna (Tachyglossus aculeatus). Australian Journal of Zoology 63 181-191. (https://doi.org/10.1071/ ZO14069)

Warren WC, Hillier LW, Marshall Graves JA, Birney E, Ponting CP, Grutzner F, Belov K, Miller W, Clarke L, Chinwalla AT et al. 2008 Genome analysis of the platypus reveals unique signatures of evolution. Nature 453 175-183. (https://doi.org/10.1038/nature06936)

Wilson JD, Auchus RJ, Leihy MW, Guryev OL, Estabrook RW, Osborn SM, Shaw G \& Renfree MB $20035 \alpha$-Androstane- $3 \alpha, 17 \beta$-diol is formed in tammar wallaby pouch young testes by a pathway involving $5 \alpha$ pregnane-3 $\alpha, 17 \alpha$-diol-20-one as a key intermediate. Endocrinology 144 575-580. (https://doi.org/10.1210/en.2002-220721)

Received 25 May 2019

First decision 25 June 2019

Revised manuscript received 25 October 2019

Accepted 19 November 2019 